\title{
Oroclinal bending in the Caledonides of western Ireland: a mid-Palaeozoic feature controlled by a pre-existing structural grain
}

\author{
Conall Mac Niocaill ${ }^{\mathrm{a}, *}$, Mark A. Smethurst ${ }^{\mathrm{b}}$, Paul D. Ryan ${ }^{\mathrm{c}}$ \\ ${ }^{a}$ Department of Earth Sciences, University of Oxford, Parks Road, Oxford, OXI 3PR, UK \\ ${ }^{b}$ Geological Survey of Norway, Leiv Eirikssons vei 39, N-7040 Trondheim, Norway \\ ${ }^{c}$ Department of Geology, National University of Ireland, Galway, Ireland
}

Received 30 October 1997; accepted 30 March 1998

\begin{abstract}
The Caledonides of the west of Ireland mark a segment of the Caledonian-Appalachian orogen where the structural grain swings from the NE-SW trend that typifies the Caledonides of northern Britain to an E-W orientation. The origin of this arcuate structure has previously been proposed to be either primary, reflecting the original geometry of promontories and embayments in the Laurentian margin in this sector of the orogen, or secondary, as evidenced by palaeomagnetically determined clockwise rotations in Silurian rocks in the region. We report the results of a palaeomagnetic investigation of the Early to middle Ordovician Mweelrea Ignimbrites (Llanvirn), from an accreted Taconic arc (the South Mayo Trough) in that part of the western Irish Caledonides that has an E-W trend. After removal of a low-temperature component of magnetisation, (L), interpreted to represent a viscous component of the earth's present field, a high-temperature component of magnetisation, $(\mathrm{H})$, was isolated at fifteen sites in four ignimbrite flows. $\mathrm{H}$ passes a palaeomagnetic fold test yielding a tilt-corrected mean remanence direction $D=132.6^{\circ}, I=29.1^{\circ}, \alpha_{95}=17.9^{\circ}$ which corresponds to a palaeopole at $36.4^{\circ} \mathrm{E}$, $9.9^{\circ} \mathrm{S}$. The pole is in reasonable agreement with established Early to middle Ordovician reference poles for Laurentia and indicates that no significant rotation occurred between the E-W South Mayo Trough and the Laurentian margin after accretion, and therefore that the curvature of this segment of the orogen is likely to be primary. This contrasts with other results from Silurian sequences to the south, which record significant post-Silurian clockwise rotations. Examination of all reliable palaeomagnetic data from the region indicates that the clockwise rotations are restricted to the rocks south of the South Mayo Trough. We propose that the rotations in the south are linked with the superposition of the pre-existing structural grain on the younger rock units during Late Silurian and Early Devonian sinistral transpression. (C) 1998 Elsevier Science B.V. All rights reserved.
\end{abstract}

Keywords: terranes; rotations; orocline; Caledonides; palaeomagnetism; Ireland

\section{Introduction}

The Caledonides of western Ireland are critical to the understanding of the Caledonian-Appalachian

\footnotetext{
* Corresponding author. Tel.: +44 (1865) 272055; Fax: +44 (1865) 272072; E-mail: conallm@earth.ox.ac.uk
}

orogen as a whole (Fig. 1A) because they link the European and North American sectors of the orogen. A complex terrane geometry is preserved (Fig. 1B), comprising, from north to south, elements of the early Palaeozoic Laurentian margin (the North Mayo Inlier), possible subduction accretion complexes and mélanges (the Clew Bay and Westport Complexes 

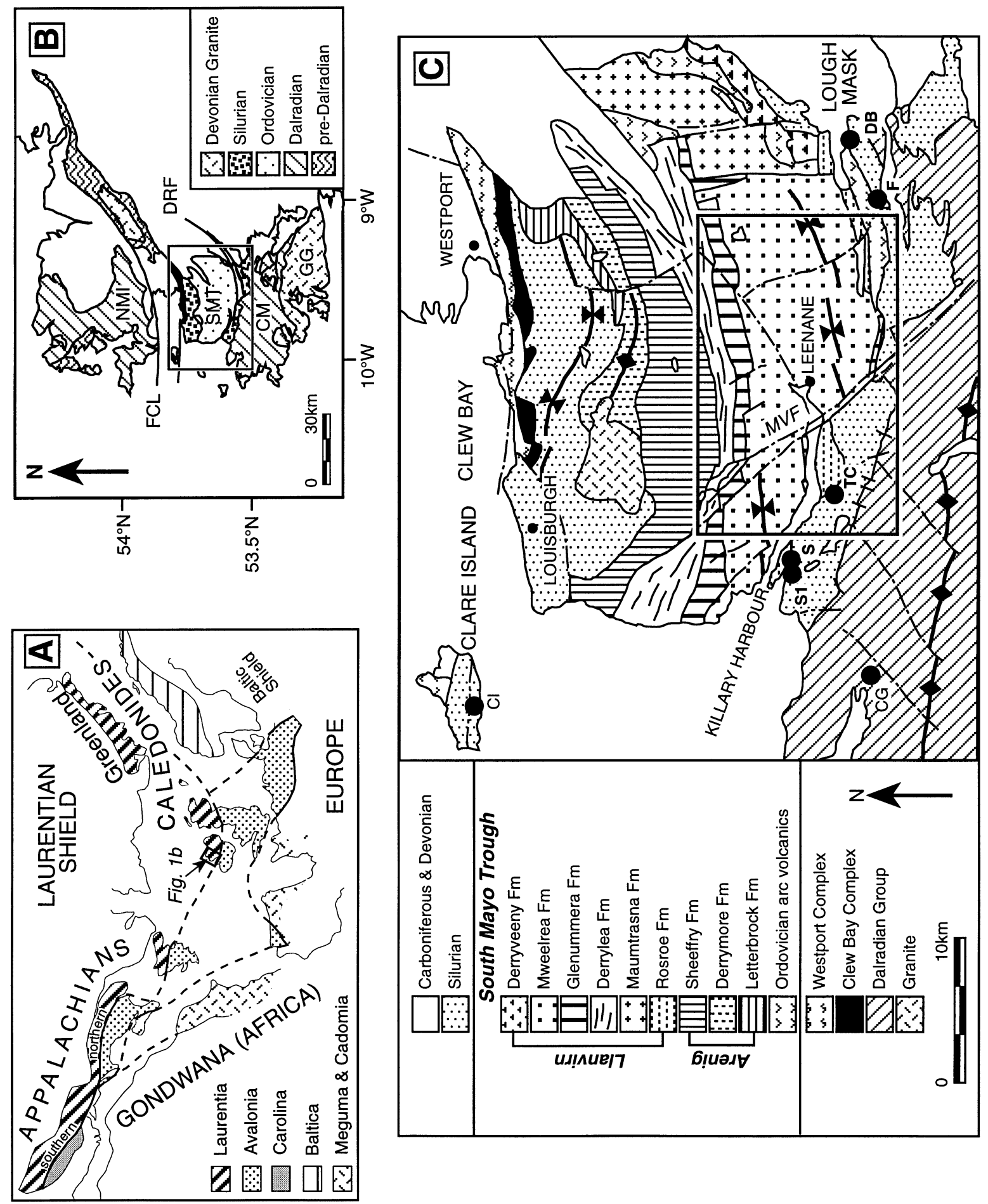
of Fig. 1C), an Early Ordovician (Taconic) fore-arc basin and volcanic arc (the South Mayo Trough) and an excised fragment of the Laurentian margin (the Connemara Massif) (Hutton and Dewey, 1986; Hutton, 1987; Williams et al., 1988; Williams, 1990; Dewey and Ryan, 1990). It is generally accepted that the terranes were assembled during the Ordovician and Silurian, as evidenced by Silurian terrane-linking sequences in Clew Bay and north Galway (stitching the South Mayo Trough and the Connemara Massif; Fig. 1B), and modified by subsequent thrusting and strike-slip faulting continuing into the Early Devonian (?) (e.g. Williams and Harper, 1991). A likely sequence of events involves the Ordovician fore-arc and arc assemblage of South Mayo colliding in dextral regime with the Laurentian margin in the Early Ordovician. The site of this collision is preserved in Clew Bay. This was followed by a Late Ordovician to Silurian sinistral regime which led to the emplacement of the Connemara terrane outboard of the collision site (Ryan and Dewey, 1991).

There has been some debate in recent years as to the origin of the arcuate form of the orogen in western Ireland, where the NE-SW structural grain that typifies much of the British Caledonides swings into an E-W orientation. Our previous palaeomagnetic results from the Silurian successions of north Galway (Fig. 1C) indicate that at least part of this curvature is secondary (Smethurst et al., 1994). Silurian rocks at the western end of the region yielded palaeomagnetic declinations that were clockwise rotated relative to Laurentia by up to $105^{\circ}$, and those at the eastern end of the region were clockwise rotated by some $40^{\circ}$ relative to Laurentia, based on a comparison with reference palaeomagnetic data from other similarly aged rocks in northern Britain and North America. There are, however, few palaeomagnetic constraints available on the regional extent of these rotations. Results from the terrane-linking Silurian sequence of Clare Island to the north (Smethurst and Briden, 1988) are broadly concordant with the expected palaeofield direction, whereas data from the Connemara Gabbros to the south (Robertson, 1988) are rotated clockwise through some $77^{\circ}$ with respect to Laurentia.

On the basis of sedimentary facies changes in the Dalradian (Late Precambrian) of northwestern Ireland and restoration of Caledonian fault displacements in this sector of the orogen, Hutton and Alsop (1996) argued that the swing in strike is primary. They concluded that the arcuate form of the orogen most likely reflects 'pre-existing trends in the pre-Caledonian Atlantic borderlands'. This is evidently something of an oversimplification because palaeomagnetic investigation has proven a secondary origin for the arcuate form of the Silurian sediments in north Galway (Smethurst et al., 1994), but the full geographic extent of the rotated units could not be determined. Therefore the issue remains as to what proportion of the arcuate features are secondary, and what proportion are primary.

To address this problem, we conducted a palaeomagnetic investigation of the Mweelrea Ignimbrites (Llanvirn), in the South Mayo Trough (SMT) which lies to the north of our previous studies in the Silurian of north Galway. The palaeomagnetism of the Mweelrea Ignimbrites has been studied by Deutsch and Somayajulu (1969) and Morris (1973). Although both studies yielded qualitative evidence for a primary magnetic remanence approximately concordant with that expected for Laurentia (Briden et al., 1989), the results are based on limited demagnetisation procedures and have large error margins. The Deutsch and Somayajulu (1969) study, in particular, was also characterised by a rather limited geographical coverage of sampling sites. Neither of the earlier palaeomagnetic studies addressed the possibility of within-terrane relative rotation.

\footnotetext{
Fig. 1. (A) Simplified cartoon marking the location of the study area within the Caledonian-Appalachian orogen, in a pre-Atlantic configuration, and illustrating the strike swing from the NE-SW trend that typifies the Caledonides of northern Britain to the E-W trend observed in western Ireland. (B) Simplified map of the major tectonic zones in western Ireland. $N M I=$ North Mayo Inlier; $F C L=$ Fair Head-Clew Bay Line (the Clew Bay Terrane is marked by the black ornament on the southern side of the bay); SMT = South Mayo Trough; $D R F=$ Doon Rock Fault; $C M=$ Connemara Massif; $G G=$ Galway Granite. These zones are briefly described in the text. (C) Geologic map of the South Mayo Trough (modified after Dewey and Ryan, 1990). The inset box shows the location of Fig. 2. MVF = Maam-Valley Faults; $\bullet=$ the locations of previous palaeomagnetic studies in the region; $D B=$ Derry Bay; $F=$ Finny; $T C=$ Tullyconor Bridge; $S 1=$ Salrock (all from Smethurst et al., 1994); $S=$ Salrock; $C I=$ Clare Island (from Smethurst and Briden, 1988 ); $C G=$ the Connemara gabbros (from Robertson, 1988).
} 


\section{Geological setting and sampling}

In this paper we follow the time scale of Tucker and McKerrow (1995) in describing series names, with the exception of the Llanvirn series, which now includes the Llandeilo as a stage (Fortey et al., 1995). In this scheme the Early Ordovician comprises the Tremadoc and Arenig (495-480 and 480-470 Ma, respectively), the middle Ordovician consists of the Llanvirn series (470-458 Ma) and the Late Ordovician comprises the Caradoc and Ashgill (458-449 and 449-443 Ma, respectively). The Silurian is subdivided into four series: the Llandovery (443-428 Ma), the Wenlock (428-423 Ma), the Ludlow (423$419 \mathrm{Ma}$ ) and the Pridoli (419-417 Ma).

The Mweelrea Ignimbrites form part of the Mweelrea Formation, a 2-km (minimum)-thick sequence of coarse-grained, trough cross-bedded sandstones with local conglomerates and slates exposed in the SMT. The sands contain volcanic, granitic, and continental metamorphic detritus. Faunal evidence (Williams, 1972) accords a late Llanvirn age to the formation, whilst the lowermost ignimbrite has been dated at $464 \pm 3.9 \mathrm{Ma}$ (Dewey and Mange, in press). The shallow water deposits mark the latest stage of development of the SMT and overlie an 8-km-thick sequence comprising volcaniclastic turbidites (Llanvirn: 470-458 Ma), overlying a silicic volcanic complex (Arenig: 480-470 Ma) attributed to a fore-arc basin (Dewey and Ryan, 1990). These in turn overlie a Lower Ordovician (Tremadoc: 495$480 \mathrm{Ma}$ ) sequence of pillowed metabasalts, spillites, keratophyric breccias and flysch deposits, interpreted to be the remnants of an Early Ordovician Island Arc (Ryan et al., 1983; Dewey and Ryan, 1990; Clift and Ryan, 1994). The abundance of metamorphic detritus implies that the Mweelrea Formation post-dates collision between the arc and the Laurentian margin (Dewey and Ryan, 1990).

Following collision of the arc with the Laurentian margin the SMT underwent at least two major phases of folding; the first being pre-Llandovery, evidenced by the unconformity between the Ordovician and the earliest (Llandovery) Silurian sediments (Dewey, 1967), and the second post-Wenlock, folding the Silurian overstep sequence between the SMT and the Connemara Massif to the south. The Mweelrea Formation occupies the core of the Mweelrea syncline, a gently plunging E-W synclinorium. Six major ignimbrite tuff bands occur within the Mweelrea

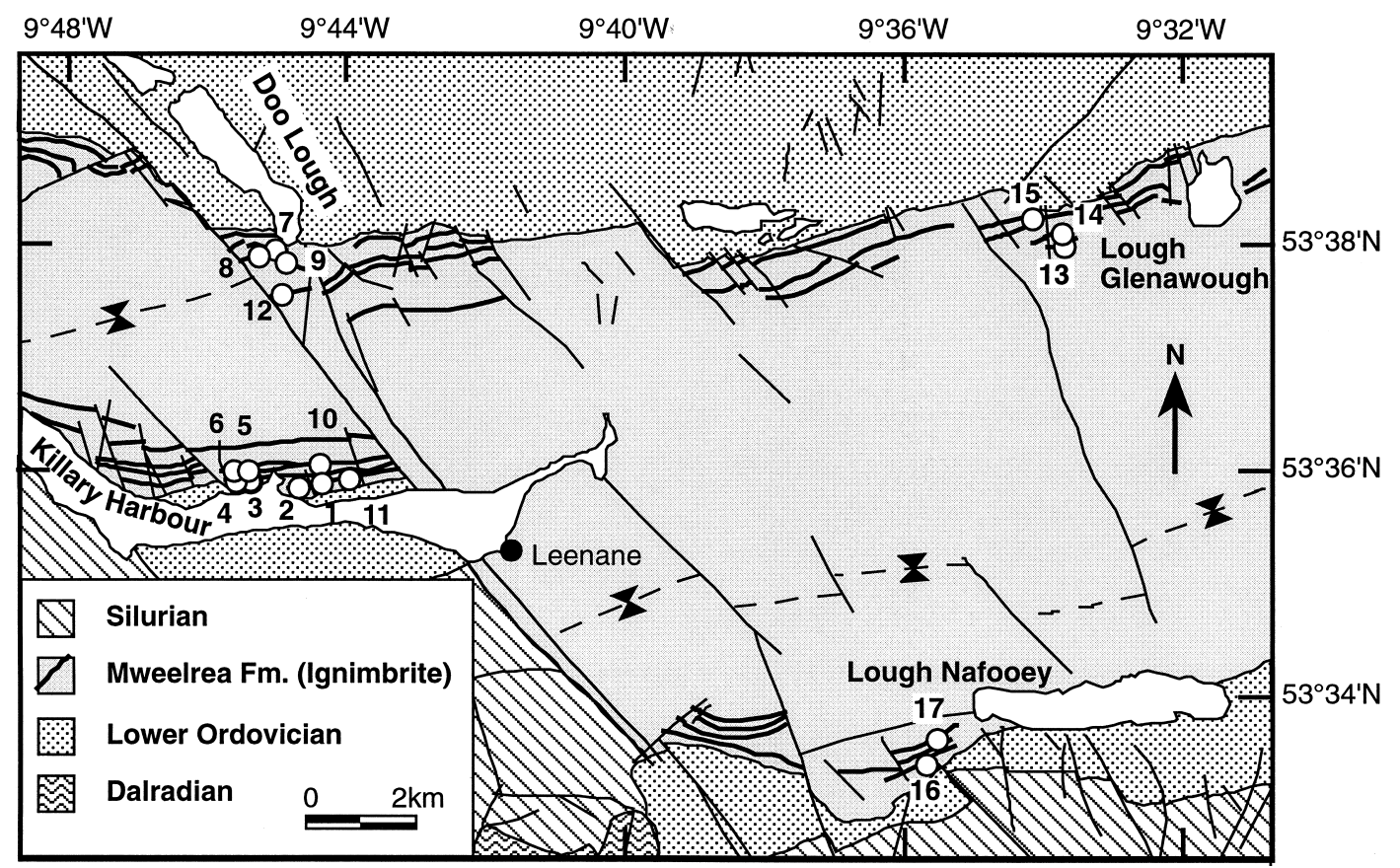

Fig. 2. Geologic map of the South Mayo Trough illustrating the location of the sampling sites within the Mweelrea Ignimbrites. 
Formation (Dewey, 1963), which vary in thickness up to $10 \mathrm{~m}$. However, they are not all laterally continuous (Stanton, 1960; Dewey, 1963). Sampling was therefore restricted to four of the more laterally continuous bands. Samples for palaeomagnetic analysis were collected at seventeen sites in the ignimbrites, at four distinct sampling localities; Killary Harbour (eight sites), Doolough (four sites), Lough Nafooey (two sites) and Glenawough (three sites) (Fig. 2). Due to the welded nature of the ignimbrites they proved to be too hard to drill in the field and therefore three or rarely two large block samples were collected from each site. The sampling programme was designed to permit the application of a palaeomagnetic fold test and to cover outcrops on both sides of the Maam-Valley fault zone, to test for relative rotation of blocks across the fault system.

\section{Palaeomagnetic analysis}

A total of 139 individual $2.5-\mathrm{cm}$ cylindrical specimens were drilled from the block samples in the laboratory. Measurements of natural remanent magnetisation (NRM) were carried out using a JR5a spin-

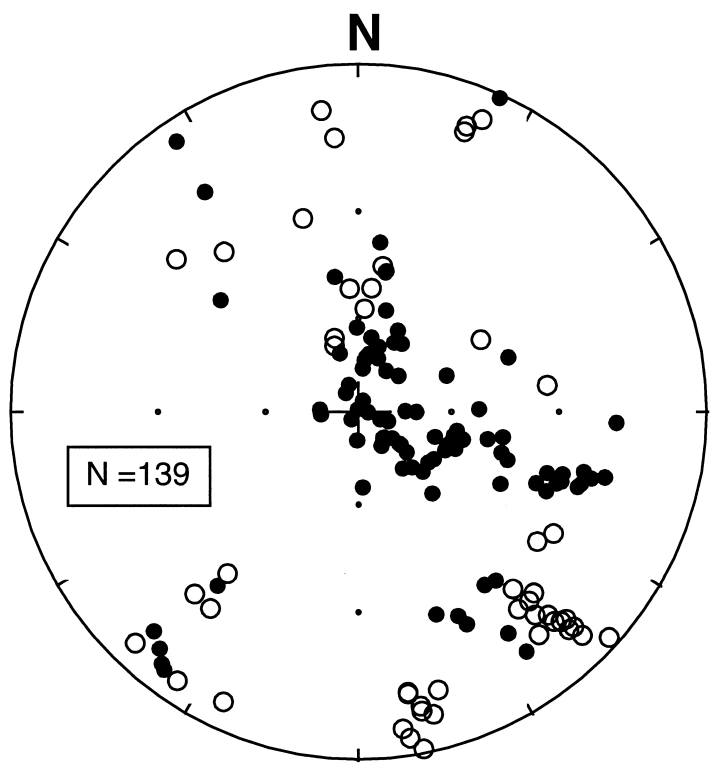

Fig. 3. Specimen NRM directions from the Mweelrea Ignimbrites. Open (closed) symbols represent projections on the upper (lower) hemisphere. Equal-area projection. ner magnetometer at the palaeomagnetic laboratory of the Geological Survey of Norway (reliably measuring down to ca. $0.1 \mathrm{~mA} / \mathrm{m}$ ). Standard progressive thermal and alternating field (AF) demagnetisation was carried out on 129 of the specimens using up to 24 steps. In a number of cases AF demagnetisation to the maximum available peak field of 90 $\mathrm{mT}$ failed to completely demagnetise the specimens. In these cases the remaining NRM was randomised using thermal treatments. Components of NRM were determined from least-squares analysis on linear segments of the demagnetisation trajectories.

To aid in the identification of remanence carriers, Curie balance and high-temperature susceptibility measurements were carried out at the Institute of Solid Earth Physics, Bergen (Norway) and the Department of Earth Sciences, Oxford University (UK), respectively.

\section{Remanence components}

NRM directions were generally directed about a north-northwest south-southeast axis with varying inclinations, with the majority having downward inclinations in the southeast quadrant (Fig. 3). NRM intensities ranged between 0.007 and $0.9 \mathrm{~A} / \mathrm{m}$, with the exception of site 13 where NRM intensities were of the order of $20-30 \mathrm{~A} / \mathrm{m}$.

Progressive demagnetisation revealed the presence of two components of NRM, which are referred to throughout the text in terms of their relative unblocking temperatures $\left(T_{\mathrm{ub}}\right)$ : L (low: $T_{\mathrm{ub}}$ generally $<400^{\circ} \mathrm{C}$ ), and $\mathrm{H}$ (high: $T_{\mathrm{ub}}$ usually $>450^{\circ} \mathrm{C}$ ). The low-temperature component $\mathrm{L}$ was usually removed after only two or three treatment steps, although occasionally it persisted to higher temperatures, overlapping with the higher-stability component. In a few cases overlapping components yielded apparently linear segments in demagnetisation trajectories (ca. $200-500^{\circ} \mathrm{C}$ ) (e.g. Fig. 4A). These linear segments were found to be coplanar with $\mathrm{L}$ and $\mathrm{H}$ and are therefore taken to be a composite of them (Fig. 4D). Where best defined, the L component was directed down to the north parallel to the present earth's field in western Ireland. Therefore we interpret $\mathrm{L}$ as a viscous remanent magnetisation of recent age. 

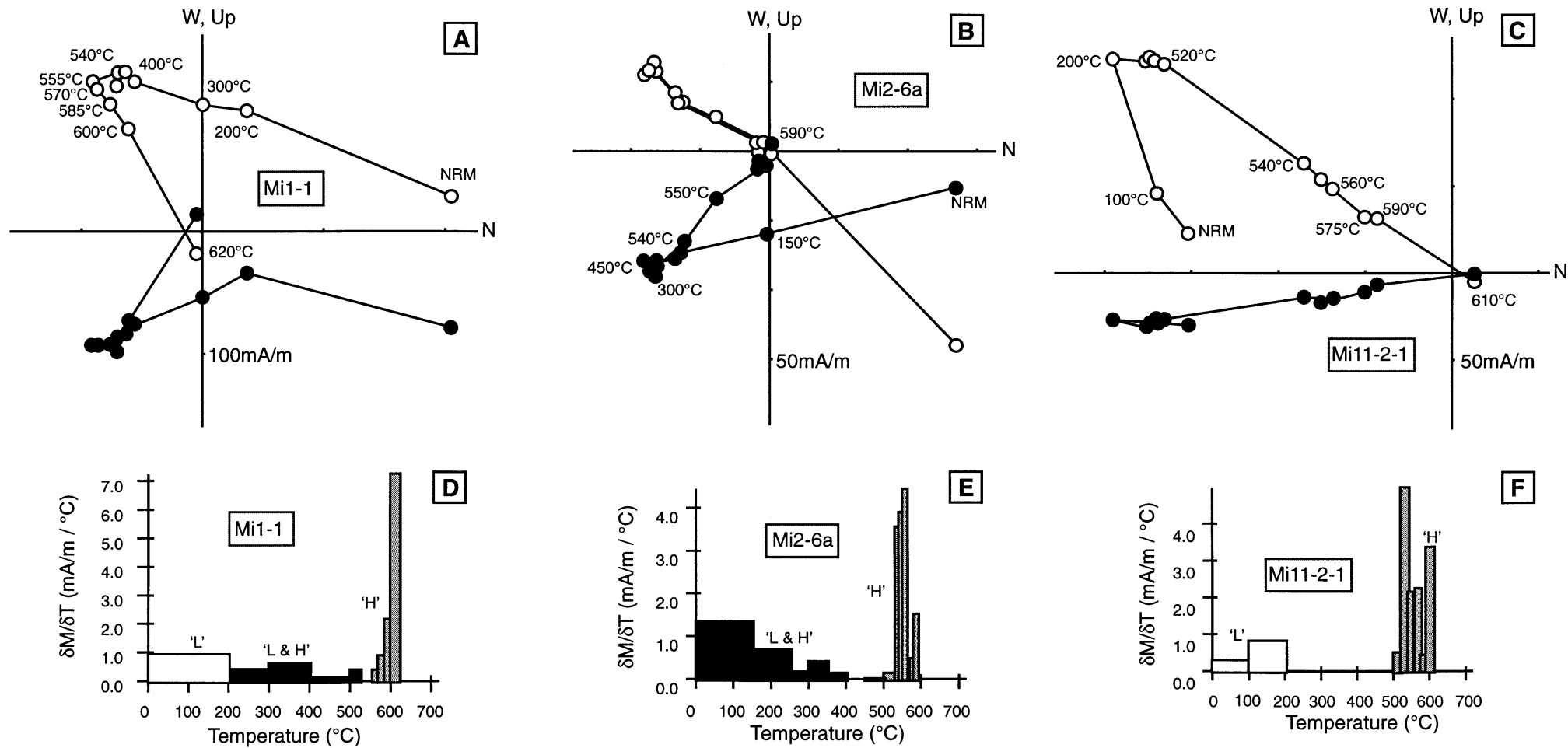

F

Fig. 4. Example orthogonal plots $(\mathrm{A}-\mathrm{C})$, with associated unblocking temperature spectra (D-F), of progressive demagnetisation data for the Mweelrea Ignimbrites from the southern limb of the Mweelrea syncline. The plots illustrate the change in magnetic remanence vector during step-wise demagnetisation. The solid line with closed symbols denotes the change in the direction of the magnetisation vector projected into the horizontal plane. The dashed line with the open symbols denotes the change in the direction of the magnetisation vector projected into the vertical plane. Straight segments in the demagnetisation trajectory indicate underlying components of the total specimen magnetisation. For a complete description see Butler (1992). Unblocking temperature spectra: the $x$-axis represents the laboratory heating and the $y$-axis indicates the net change of magnetisation per unit heating, the shaded regions indicate the amounts of magnetisation attributed to the different components. 

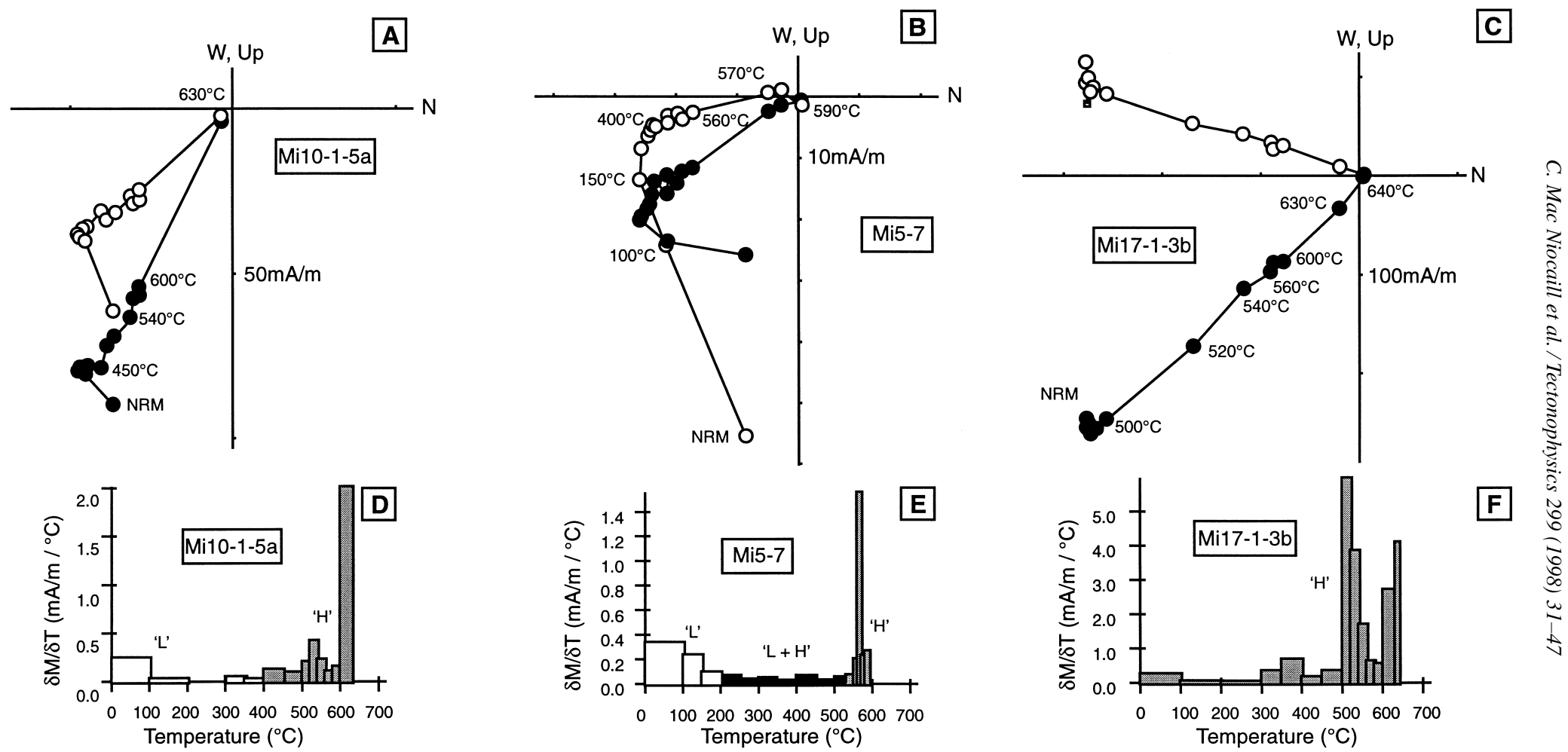

Fig. 5. Further example orthogonal plots, with associated unblocking temperature spectra, of progressive demagnetisation data for the Mweelrea Ignimbrites from the southern limb of the Mweelrea syncline. Conventions and symbols are as for Fig. 4. 

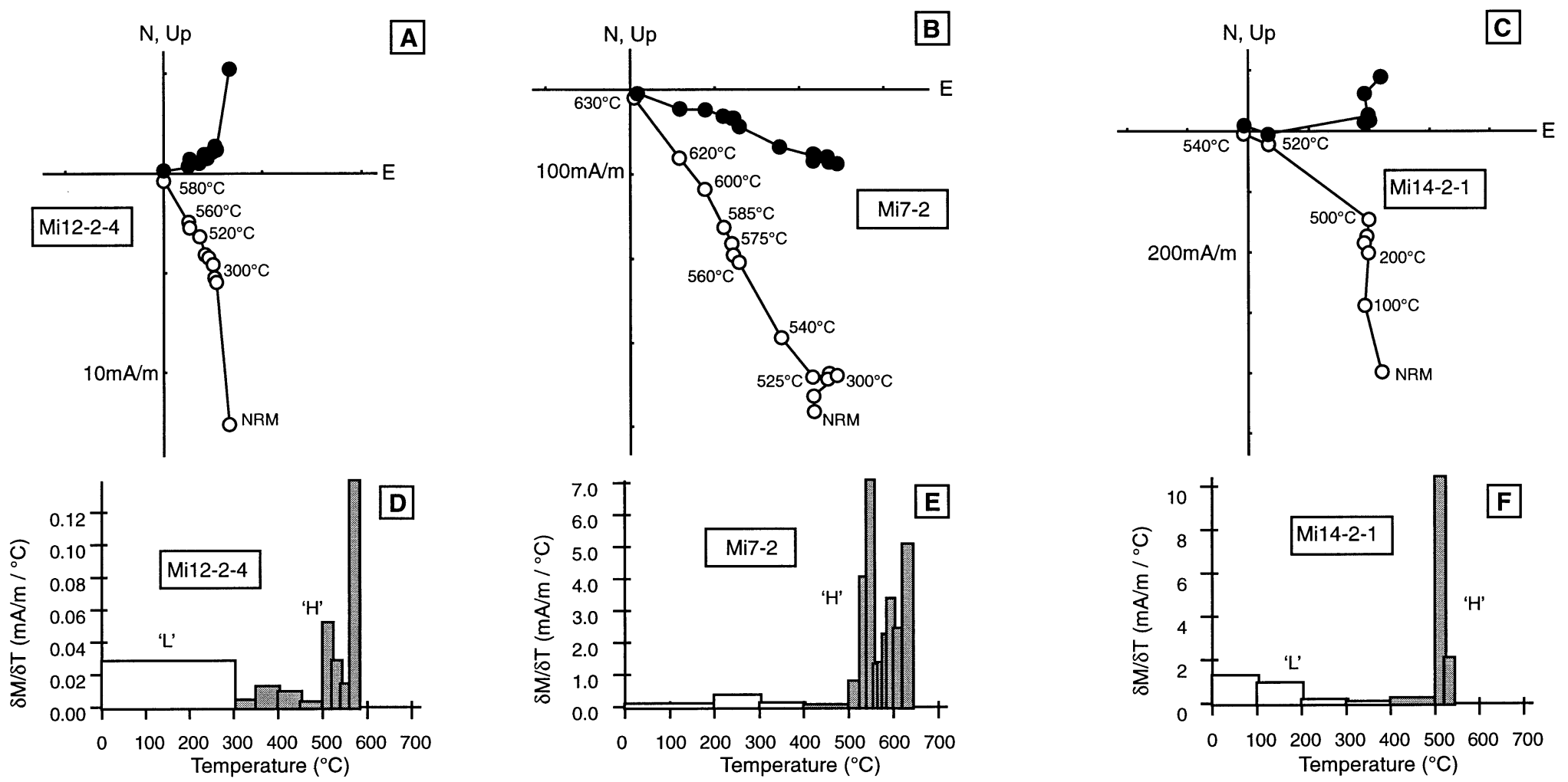

Fig. 6. Example orthogonal plots, with associated unblocking temperature spectra, of progressive demagnetisation data for the Mweelrea Ignimbrites from the northern limb of the Mweelrea syncline. Conventions and symbols are as for Fig. 4. 
Table 1

High-temperature remanence components from the Mweelrea Ignimbrites

\begin{tabular}{|c|c|c|c|c|c|c|c|c|c|}
\hline \multirow[t]{2}{*}{ Site No. } & \multirow[t]{2}{*}{ Band } & \multirow[t]{2}{*}{$n / n_{\mathrm{o}}(N)$} & \multicolumn{2}{|l|}{ In situ } & \multirow[t]{2}{*}{$k$} & \multirow[t]{2}{*}{$\alpha_{95}$} & \multicolumn{2}{|c|}{ Tilt corrected } & \\
\hline & & & $D$ & $I$ & & & $D$ & $I$ & \\
\hline \multicolumn{10}{|c|}{ High-stability remanence directions } \\
\hline Mi1 & $1 \mathrm{~S}$ & 6/7 (3) & 127.1 & -41.8 & 333.9 & 3.7 & 137.9 & -6.1 & \\
\hline $\mathrm{Mi} 2$ & $1 \mathrm{~S}$ & $11 / 12(3)$ & 139.4 & -21.8 & 70.6 & 5.5 & 140.3 & 16.2 & \\
\hline Mi3 & $2 \mathrm{~S}$ & $6 / 6(3)$ & 145.6 & 0.0 & 278 & 4.0 & 136.6 & 38.5 & \\
\hline Mi4 & $2 \mathrm{~S}$ & $10 / 10(3)$ & 158.4 & -16.0 & 85.7 & 5.3 & 157.1 & 27.4 & \\
\hline Mi5 & $3 \mathrm{~S}$ & $8 / 8(3)$ & 132.4 & 20.5 & 38.9 & 9.0 & 105.7 & 48.0 & \\
\hline Mi6 & $3 S$ & $0 / 6(2)$ & - & - & - & - & - & - & \\
\hline Mi7 & $2 \mathrm{~N}$ & $4 / 5(2)$ & 116.2 & 72 & 60.3 & 11.9 & 143.0 & 5.5 & \\
\hline Mi8 & $3 \mathrm{~N}$ & $5 / 5(2)$ & 112.1 & 68.8 & 52 & 10.7 & 147.8 & 26.1 & \\
\hline Mi9 & $3 \mathrm{~N}$ & $5 / 5(3)$ & 116.8 & 64.1 & 183.6 & 5.7 & 145.9 & 21.3 & \\
\hline Mi10 & $3 S$ & $11 / 11(3)$ & 113.1 & 14.4 & 307.1 & 2.6 & 094.5 & 30.6 & \\
\hline Mi11 & $1 \mathrm{~S}$ & 9/9 (3) & 172.0 & -36.2 & 1520 & 1.3 & 170.9 & 5.6 & \\
\hline Mi12 & $5 \mathrm{~N}$ & $6 / 6(3)$ & 064.9 & 65.5 & 118.5 & 6.2 & 121.5 & 43.0 & \\
\hline Mi13 & $3 \mathrm{~N}$ & $0 / 7$ (3) & - & - & - & - & - & - & \\
\hline Mi14 & $2 \mathrm{~N}$ & $8 / 8$ (3) & 088.6 & 40.5 & 274.3 & 3.4 & 109.9 & 10.6 & \\
\hline Mi15 & $1 \mathrm{~N}$ & $5 / 5(2)$ & 115.9 & 60.5 & 358.7 & 4.1 & 137.2 & 16.9 & \\
\hline Mi16 & $1 \mathrm{~S}$ & 9/9 (3) & 129.1 & -20.5 & 33.6 & 9.0 & 124.1 & 37.6 & \\
\hline \multirow[t]{2}{*}{ Mi17 } & $3 \mathrm{~S}$ & $10 / 10(3)$ & 137.3 & -15.0 & 253.7 & 3.1 & 130.5 & 45.9 & \\
\hline & $N$ & $D$ & $I$ & $k$ & $\alpha_{95}$ & Long. & Lat. & $\mathrm{d} \psi$ & $\mathrm{d} \chi$ \\
\hline \multicolumn{10}{|c|}{ Mean direction based on sites } \\
\hline In situ & 15 & 129.8 & 18.1 & 3.2 & 25.5 & 041.8 & -14.2 & 13.7 & 26.5 \\
\hline Tilt-corrected & 15 & 134.7 & 25.7 & 11.4 & 11.8 & 035.4 & -12.6 & 6.9 & 12.7 \\
\hline \multicolumn{10}{|c|}{ Fold test: positive $\left(\rho=0.05, f_{\mathrm{o}}=0.04, f_{\mathrm{c}}=0.26\right)$} \\
\hline \multicolumn{10}{|c|}{ Mean direction based on flows } \\
\hline Tilt corrected & 4 & 132.6 & 29.1 & 27.4 & 17.9 & 036.4 & -09.9 & 10.9 & 19.7 \\
\hline
\end{tabular}

$n / n_{\mathrm{o}} /(N)=$ number of specimens used in the analysis/number of specimens demagnetised/number of block samples; $D / I=$ mean declination/inclination, $k / \alpha_{95}=$ the Fisher (1953) precision parameter/half-angle of $95 \%$ confidence about the mean. For the groups of sites $N=$ number of sites, Long./Lat. = longitude and latitude of the associated pole, $\mathrm{d} \psi / \mathrm{d} \chi=$ semi-axes of cones of $95 \%$ confidence about the pole. The fold-test is that of McFadden and Jones (1981); $\rho=$ probability; $f_{\mathrm{o}}=$ observed value of $f ; f_{\mathrm{c}}=\operatorname{critical}$ value of $f$. For the final direction based on flows $N=$ number of flows.

The high-stability component $\mathrm{H}$ was identified at fifteen of the seventeen sampling sites and site-level $\mathrm{H}$-component directions are given in in-situ and 'unfolded' forms in Table 1. Representative specimens are illustrated in Figs. 4-6. The $\mathrm{H}$ component was directed with shallow to intermediate inclinations towards the southeast in in-situ form at sites on the southern limb of the Mweelrea syncline (Figs. 4 and 5 ), whereas it was directed steeply downward to the east or southeast in in-situ form at sites on the northern limb (Fig. 6). In a few cases the thermal stability range of the $\mathrm{H}$ component extended beyond the Curie point of magnetite, persisting up to $640^{\circ} \mathrm{C}$ indicating that at least some of the $\mathrm{H}$ component is carried by haematite (e.g. Fig. 5C). The presence of both mag- netite and haematite in these samples is confirmed by rock magnetic experiments (see below).

\section{Magnetic mineralogy}

Representative IRM acquisition curves are shown in Fig. 7. Two types of behaviour were recognised. In the first type saturation was achieved in fields of 200-300 mT, with backfield measurements yielding coercivities of remanence of some 30-50 mT (e.g. Fig. 7; sample Mi4-5). In the second type, saturation was not achieved in fields up to $300 \mathrm{mT}$, though the slope of most curves decreased. This indicates the presence of a high-coercivity mineral phase. 


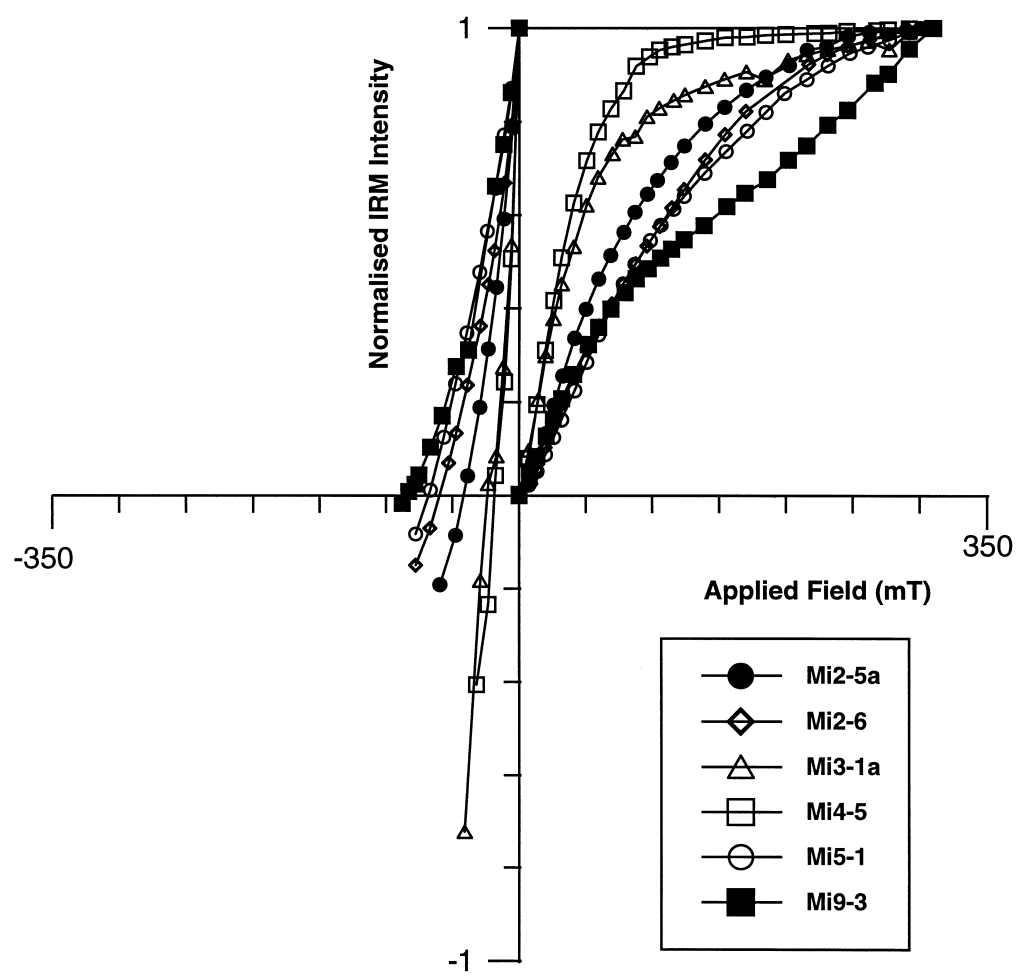

Fig. 7. Representative IRM acquisition curves for samples from the Mweelrea Ignimbrites. Samples were stepwise subjected to progressively higher magnetic fields and the induced magnetisation measured after each step. Magnetisation intensities are normalised. In most cases saturation is not achieved in fields up to $300 \mathrm{mT}$ indicating the presence of high-coercivity magnetic fraction in the samples. On the basis of the demagnetisation behaviour of the samples during thermal demagnetisation and rock magnetic experiments we conclude that this higher-coercivity fraction is haematite.

Thermomagnetic analyses yielded similar information: the majority of samples having well defined Curie points for magnetite (or low-titanium titanomagnetite) (Fig. 8A-C). In a number of cases almost reversible curves were obtained with two Curie points; at $530-580^{\circ} \mathrm{C}$ and $650-680^{\circ} \mathrm{C}$ (Fig. 8D), indicating that haematite is the high-coercivity magnetic mineral phase. High-temperature susceptibility measurements (Fig. 8E,F) produced similar results to the thermomagnetic curves, though they yielded more sharply defined Curie points for magnetite than the latter technique.

Taken together, the IRM acquisition curves, the thermomagnetic analyses and the high-temperature susceptibility measurements all indicate the presence of two main magnetic mineral phases: magnetite and haematite. This is consistent with the unblocking temperature spectra obtained from thermal demagnetisation. As no difference is noted between the directions of the $\mathrm{H}$ component carried by magnetite and haematite, it is proposed that the haematite represents an early deuteric oxidation as the ignimbrites were being erupted or shortly after.

\section{Fold tests and the timing of magnetisation}

Site-level H-component directions are illustrated in Fig. 9 and tabulated in Table 1, in both the insitu and tilt-corrected forms. Tilt-correction brings about a significant decrease in the dispersion of the site-mean directions. In assessing this improvement the approximate fold test of McFadden and Jones (1981) was utilised as the precision parameters for the populations on both limbs are significantly different. The difference in precision parameters between each limb may be due to sampling bias (nine sites on the south limb and six sites on the northern 

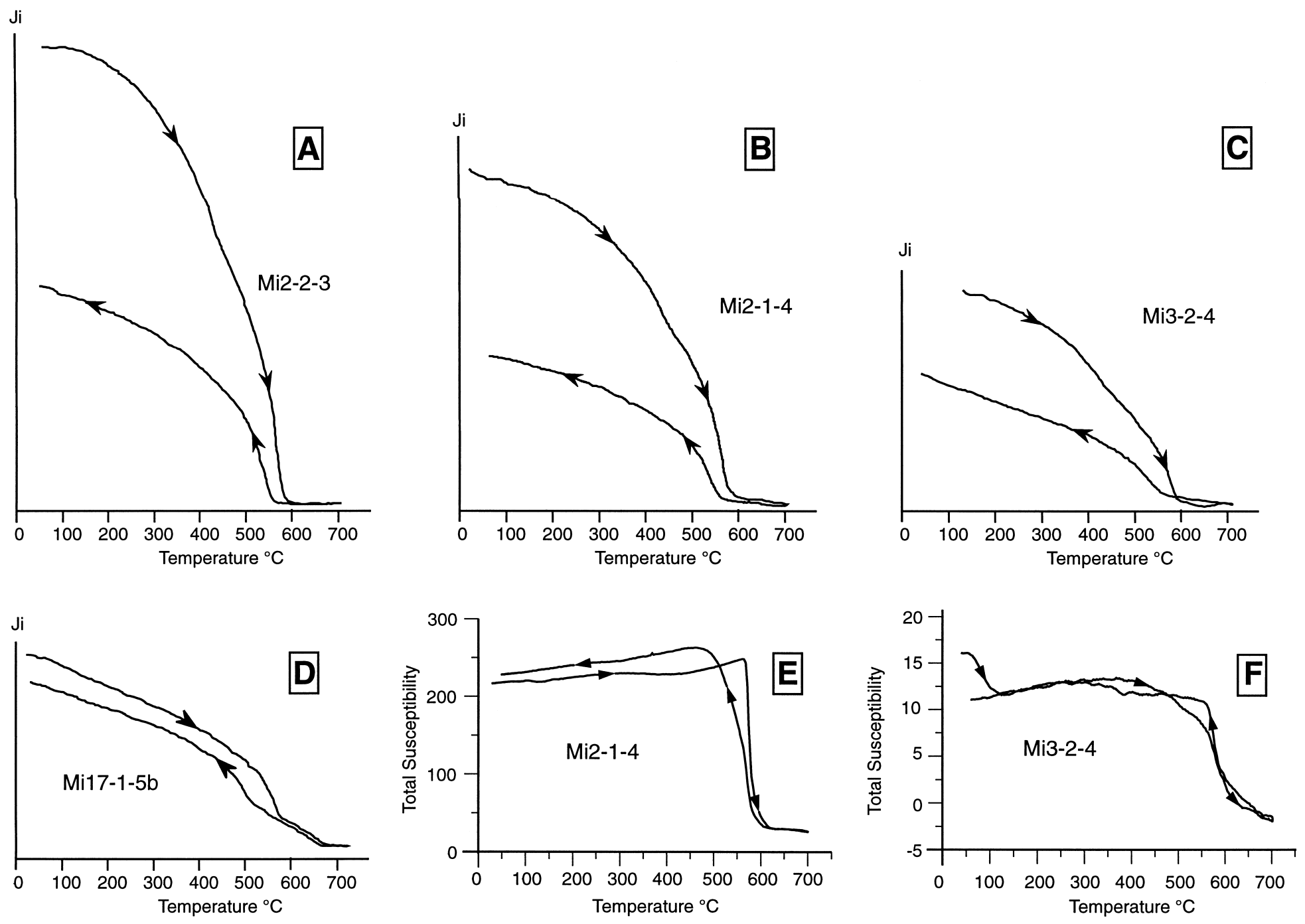

Fig. 8. Example thermomagnetic curves (A-D) and high-temperature susceptibility determinations (E and F) for the Mweelrea Ignimbrites. The samples in (A-C) exhibit irreversible heating and cooling curves with Curie points for magnetite (or low-Ti titanomagnetite). The sample in (D) also yields a Curie point for haematite. The high-temperature susceptibility determinations (E and F) concur with results from the thermomagnetic measurements (compare $\mathrm{E}$ and $\mathrm{F}$ with $\mathrm{B}$ and $\mathrm{C}$ ). 

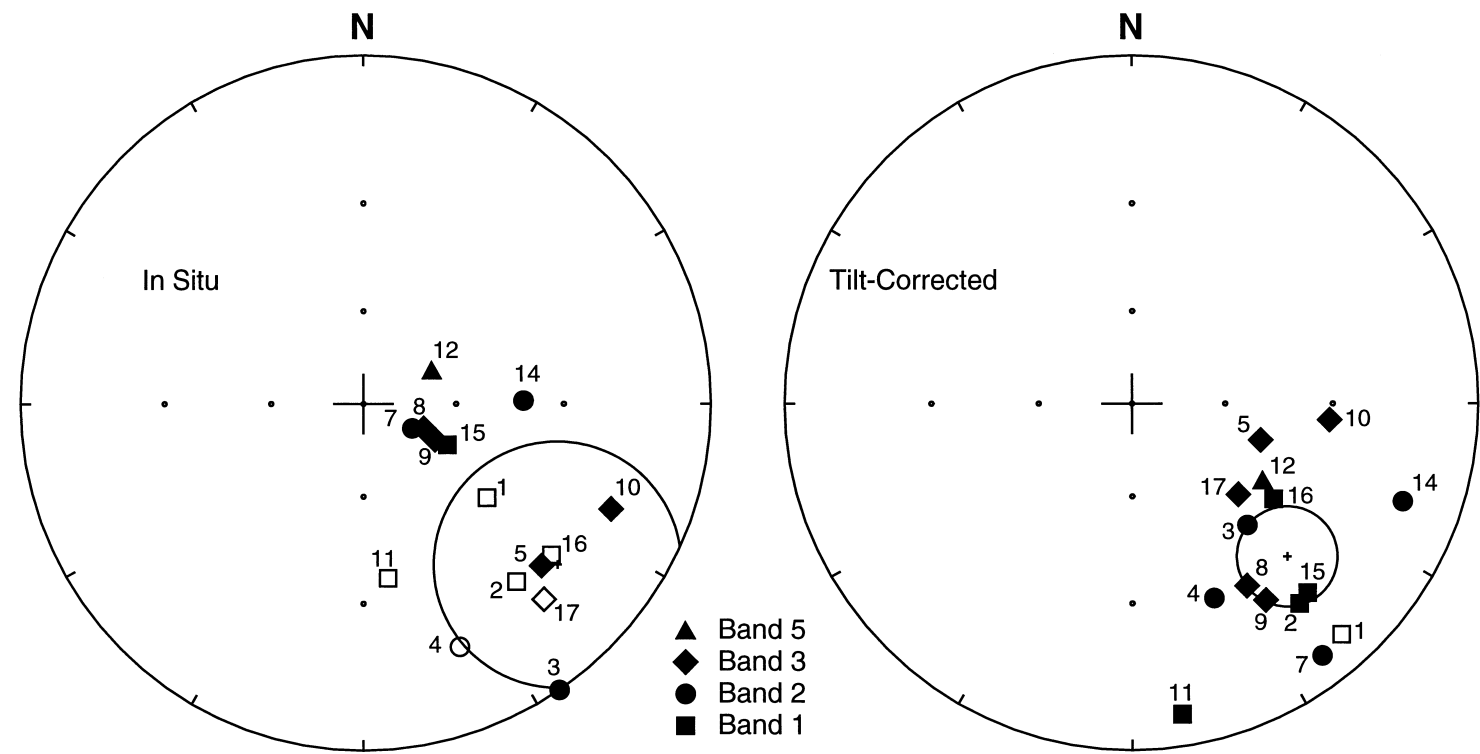

Fig. 9. Stereographic projection of site-level H-component remanence directions in-situ and in tilt-corrected co-ordinates. Note the decreased dispersion in the site means upon unfolding. Conventions and symbols are as for Fig. 3.

limb), or the lavas having small primary dips. Using this test the hypothesis of a common mean direction for the two populations from the northern limb and the southern limb can be rejected at the $99 \%$ confidence level for the in-situ site mean directions, but cannot be rejected at the $95 \%$ confidence level for the tilt-corrected directions. Thus, the fold test is positive and therefore $\mathrm{H}$ is taken to pre-date the folding. Also, correction for folding was sufficient to reconcile results from either side of the MaamValley fault system, ruling out oblique relative rotation caused by the faults. We also examined the data for any correspondence between the bedding strikes and remanence declinations, in case any significant vertical axis rotation had occurred between sites. No such correspondence was found and we therefore take our result to be representative for the South Mayo Trough as a whole for the time of ignimbrite eruption.

The resulting mean direction, $D=134.7^{\circ}$, $I=25.7^{\circ}\left(N=15\right.$ sites, $\left.\alpha_{95}=11.8^{\circ}\right)$, based on site means, yields a palaeopole position at $035.4^{\circ} \mathrm{E}$, $12.6^{\circ} \mathrm{S}(\mathrm{d} \psi / \mathrm{d} \chi=6.0 / 12.7)$. Each of the flows may, however, only represent a spot reading of the magnetic field. There is evidence for a degree of early oxidation of the flows which would indicate some averaging of secular variation and the scatter of directions within each flow (Fig. 9) would also indicate a degree of averaging of secular variation within each flow. We have chosen to be conservative, however, and our final result is based on flows, rather than sites. This does not significantly alter the mean direction: $D=132.6^{\circ}, I=29.1^{\circ}(N=4$ flows, $\alpha_{95}=17.9^{\circ}$ ) with a corresponding palaeopole at $036.4^{\circ} \mathrm{E}, 9.9^{\circ} \mathrm{S}(\mathrm{d} \psi / \mathrm{d} \chi=10.9 / 19.7)$. The mean result reported here is statistically indistinguishable from that of Morris (1973) $\left(D=133^{\circ}, I=30^{\circ}\right)$, but supersedes the earlier result in that the new data are based on thorough demagnetisation of specimens using modern equipment.

\section{Discussion}

In order to identify the crustal blocks that have undergone rotations in the region we compared all primary palaeomagnetic results from the west of Ireland with the reference apparent polar wander (APW) path for Laurentia of Mac Niocaill and Smethurst (1994). We started by using the APW path to determine the expected remanence direction for each of the Irish studies, as if they were part of stable Laurentia (Fig. 10; Table 2). These were then compared with the actual (tilt corrected) rema- 

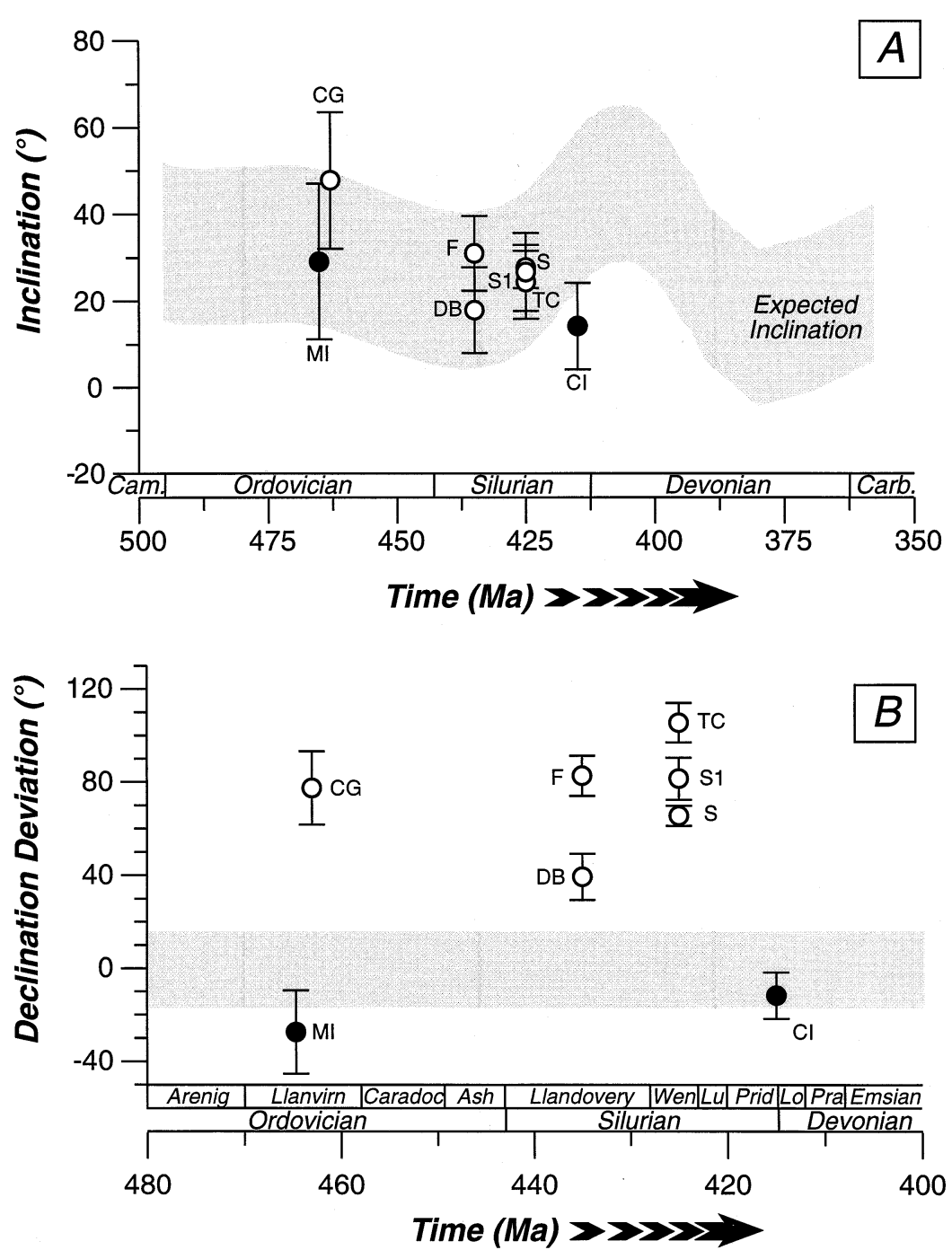

Fig. 10. (A) The inclinations, with associated errors, from the various palaeomagnetic studies from the Caledonides of western Ireland (Table 2) compared with their expected inclinations as calculated from the Apparent Polar Wander (APW) Path for Laurentia (Mac Niocaill and Smethurst, 1994). Inclinations have all been standardised to a reverse polarity. Circles are for studies from south of the South Mayo Trough, and dots are for studies from north of and including the South Mayo Trough. Labels beside the data points refer to the codes for the studies summarised in Table 2. Note that they are in relatively good agreement, falling within error of the swath for the APW path, with the exception of the result from the Silurian Red Beds of Clare Island (CI; Smethurst and Briden, 1988) which are interpreted to have undergone a degree of inclination shallowing. (B) The deviation in declination of the various palaeomagnetic studies in western Ireland studies (Table 2). The deviation has been calculated by subtracting the expected declination, as calculated from the APW path, from the measured declination for each study. Thus non-rotated rocks will plot close to the zero value on the $y$-axis, rocks that have undergone clockwise rotations will have positive $y$-axis values and those that have undergone anticlockwise rotations will have negative $y$-axis values. Note that the major observed rotations have a strong geographic, not temporal, bias and are restricted to those units south of the South Mayo Trough, indicating that the curved nature of the orogen in this sector of the Caledonides is a primary feature to the north of and including the South Mayo Trough. Abbreviations for the series names are as follows: Ash = Ashgill; Wen = Wenlock; $L u=$ Ludlow; Prid $=$ Pridoli; $L o=$ Lochlovian; Pra $=$ Pragian. 
Table 2

Summary of palaeomagnetic data from the Caledonides of western Ireland

\begin{tabular}{|c|c|c|c|c|c|c|c|c|c|c|}
\hline \multirow[t]{2}{*}{ Location (Code) } & \multirow[t]{2}{*}{ Age } & \multicolumn{3}{|c|}{ Measured directions } & \multicolumn{3}{|c|}{ Expected directions } & \multirow{2}{*}{$\begin{array}{l}\text { Rotation } \\
R \pm \Delta R\end{array}$} & \multirow{2}{*}{$\begin{array}{l}\text { Flattening } \\
F \pm \Delta F\end{array}$} & \multirow[t]{2}{*}{ Reference } \\
\hline & & $D$ & $I$ & $\alpha_{95}$ & $D$ & $I$ & $A_{95}$ & & & \\
\hline \multicolumn{11}{|l|}{ Silurian } \\
\hline Clare Island (CI) & 418 & 184.0 & 14.2 & 10.0 & 195.6 & 14.2 & 15.5 & $-11.6 \pm 18.1$ & $25.0 \pm 14.8$ & Smethurst and Briden, 1988 \\
\hline Salrock (S1) & 425 & 262.2 & 26.7 & 9.0 & 180.9 & 27.0 & 15.5 & $81.3 \pm 16.1$ & $0.3 \pm 14.3$ & Smethurst et al., 1994 \\
\hline Salrock (S) & 425 & 246.3 & 27.3 & 4.3 & 180.9 & 27.0 & 15.5 & $65.4 \pm 14.5$ & $-0.3 \pm 12.9$ & Smethurst and Briden, 1988 \\
\hline Tully Conor (TC) & 425 & 286.2 & 24.4 & 8.5 & 180.9 & 27.0 & 15.5 & $105.3 \pm 15.8$ & $2.6 \pm 14.1$ & Smethurst et al., 1994 \\
\hline Finny $(F)$ & 435 & 254.9 & 31.0 & 8.6 & 172.4 & 22.2 & 15.6 & $82.5 \pm 15.7$ & $-8.8 \pm 14.3$ & Smethurst et al., 1994 \\
\hline Derry Bay (DB) & 435 & 211.7 & 17.9 & 10.4 & 172.4 & 22.2 & 15.6 & $39.3 \pm 15.9$ & $4.3 \pm 14.8$ & Smethurst et al., 1994 \\
\hline \multicolumn{11}{|l|}{ Ordovician } \\
\hline Connemara Gabbro (CG) & 460 & 237.5 & 47.8 & 15.7 & 160.2 & 31.7 & 16.8 & $77.3 \pm 24.8$ & $-16.1 \pm 18.4$ & Robertson, 1988 \\
\hline Mweelrea (MI) & 465 & 132.6 & 29.1 & 17.9 & 158.5 & 33.2 & 16.8 & $-25.9 \pm 23.1$ & $-4.1 \pm 19.6$ & This study \\
\hline
\end{tabular}

Age $=$ age of magnetization; Code $=$ lettering used to denote results and sampling locations in the figures. All other abbreviations are as for Table 1. All directions are tabulated as reverse polarity. The expected declinations and inclinations are calculated from the reference APW path of Mac Niocaill and Smethurst (1994) for Laurentia. The rotation $(R)$ and flattening $(F)$ parameters and their associated errors were calculated using the method of Beck (1980) and Demarest (1983).

nence directions from the Irish studies. In terms of remanence inclination, all but one of the Irish results are consistent with the reference data for Laurentia (Fig. 10A). The one exception is the low-inclination result from red mudstones and siltstones of the Bunnamohaun Formation, Clare Island (CI in Fig. 10; Smethurst and Briden, 1988). Smethurst and Briden (1988) concluded that the anomalously low inclination carried by the Bunnamohaun Formation is the result of early dewatering and compaction in the fine-grained sediment.

In contrast, the observed declinations in several of the Irish studies deviate significantly from those predicted from the reference APW path (Fig. 10B). The differences between the actual and expected declinations are estimates of the net vertical axis rotation of the studied tectonic units (blocks) relative to the stable Laurentian margin (Table 2). It is readily apparent that the observed rotations have a strong geographic, and not temporal, bias and are restricted to rocks to the south of the South Mayo Trough. This geographic distribution of rotated blocks has important implications for the evolution of the orogen in that both the studies from Clare Island and the Mweelrea Ignimbrites (CI and MI in Fig. 10) are from areas with an E-W strike (Fig. 1C) and not the NE-SW strike that typifies the orogen in most of the British Isles. The agreement of the palaeomagnetic results from both Clare Island and
Mweelrea with the palaeomagnetic directions from stable Laurentia points to the orogen having an original curved or arcuate structure. We postulate that this most likely relates to the presence of promontories and embayments in the Laurentian margin as proposed by Hutton and Alsop (1996). These promontories and embayments are likely to have controlled and/or modified, the style and geometry both of younger sedimentary basins and the structural grain of younger deformational structures.

With respect to the rotated Silurian rocks to the south of the South Mayo Trough it would appear that the arcuate structural grain of these sequences is secondary, resulting from late Caledonian compression and transpression, with the SMT behaving as an indentor. We cannot yet determine whether the Silurian rocks were originally deposited in a linear basin or whether there was a small degree of original curvature in the overall basin geometry. As noted earlier by Smethurst et al. (1994), rotating the local bedding strikes of the rotated Silurian blocks by amounts which bring them into alignment also brings the palaeomagnetic directions into approximate agreement. However, the 'strike' correction brings the Wenlock results from the Salrock Formation (S, S1 and TC in Fig. 10) some $10^{\circ}$ anticlockwise of the Llandovery results from the Lough Mask Formation (DB and F in Fig. 10). According to the reference APW path, they should fall some $25^{\circ}$ 

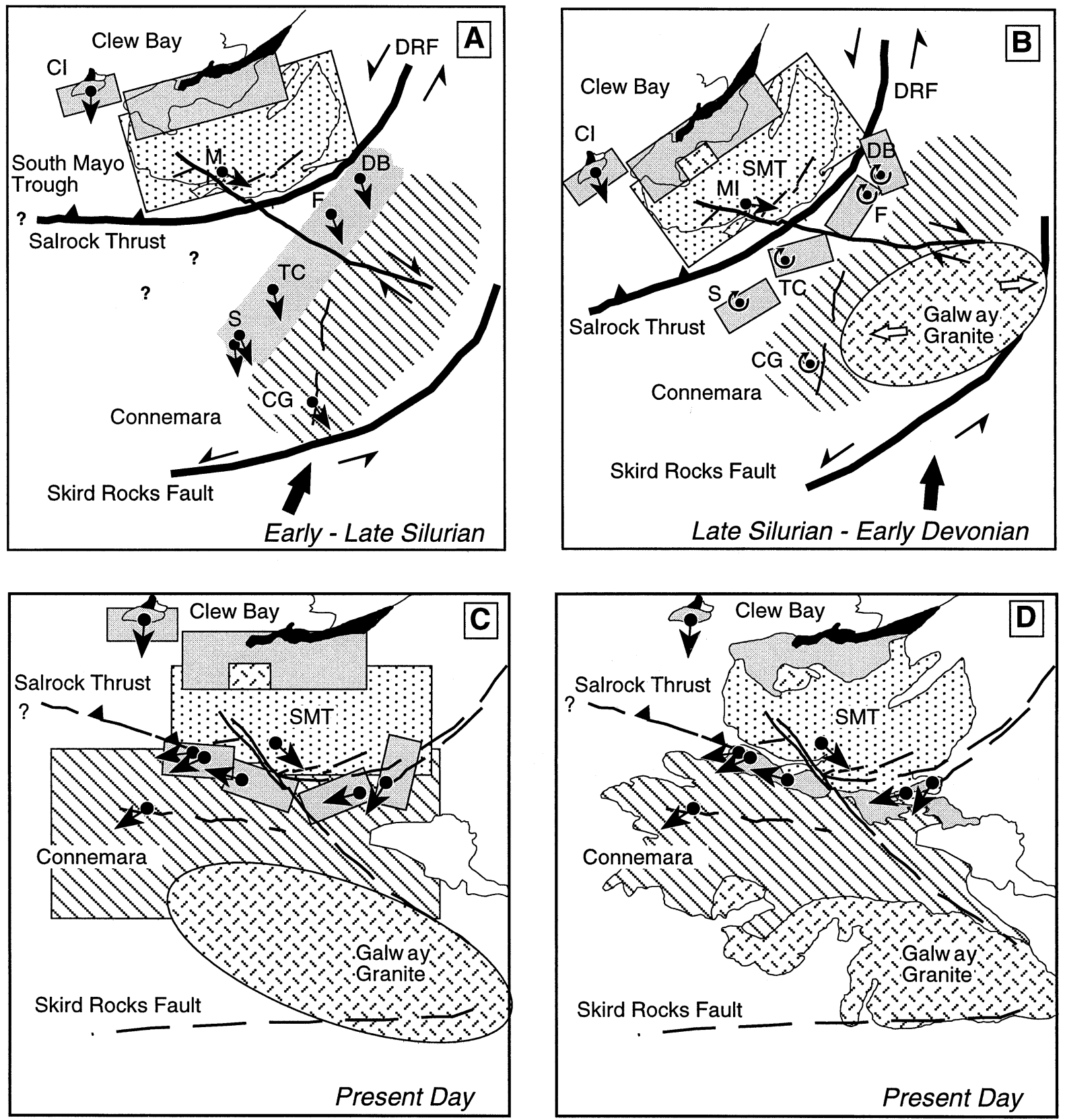

Fig. 11. Schematic cartoon illustrating the rotation history of the various crustal blocks for which reliable palaeomagnetic data exist from western Ireland. All reconstructions are restored to their original orientations relative to the magnetic north. Remanence declinations are marked by arrows connected to small dots. $S M T=$ South Mayo Trough; $D R F=$ Doon Rock Fault, and the abbreviations for the various palaeomagnetic studies are as for Table 2. In (A) the orientations of tectonic units outboard of the SMT are based on anomalies in remanence declination from the various regions (see Fig. 10). The 'fanning' in declinations in the Silurian rocks is due to apparent polar wander between remanence acquisition in the different parts of the Silurian sequence. (B) The evolution in Late Silurian and Early Devonian time, with sinistral shearing along the Skird Rocks Fault in a transpressive regime and the emplacement of the Galway Granite contributing to the displacement and clockwise rotation of the Connemara Massif. The South Mayo Trough appears to have acted as a passive indentor with the Silurian units being clockwise rotated and 'wrapped around' the pre-existing structural grain. (C) The present-day disposition of the blocks in cartoon form, and (D) a schematic summary of the present-day geology with the palaeomagnetic declinations shown. 
clockwise of the Llandovery results. Two phases of rotation were proposed by Smethurst et al. (1994) to account for this. A post-Llandovery to pre-Wenlock phase, which rotated the Llandovery rocks clockwise by some $35^{\circ}$ or so, and a later post-Wenlock phase which contributed the balance of the regionally distributed clockwise rotations. Alternatively, small discrepancies between the strike-corrected data and the reference path might indicate a difference between the initial strike of the Llandovery rocks and the initial strike of the Wenlock strata. In this case it would not be strictly correct to restore strikes from all Silurian rocks around the orocline to a single initial structural trend, as was done by Smethurst et al. (1994).

The rotation history of the various crustal blocks in the west of Ireland is depicted in cartoon form in Fig. 11. We have used the deviations in declination in Fig. 10 and Table 2 to restore tectonic units south of the South Mayo Trough to their original orientations in relation to the trough. The change in orientation of the Laurentian margin and South Mayo Trough is determined from the reference APW path for Laurentia. We propose that the rotations observed in the units to the south of the South Mayo Trough, relative to Laurentia and its margin, are related to Late Silurian and Early Devonian transpression and strike-slip faulting to the south of Connemara. This transpression was concomitant with the emplacement of the Galway granite along the line of the Skird Rock Fault (the Antrim-Galway Line of Ryan et al., 1995), a possible extension or splay of the Southern Uplands Fault of Scotland (Max and Ryan, 1975) in the region of Galway Bay (Fig. 11B). As the granite was emplaced, Connemara was rotated clockwise by about $77^{\circ}$ relative to the South Mayo Trough and displaced towards the trough, to accommodate the intrusion, producing a zone of transpression between the Connemara Massif and the SMT. Within this zone of transpression the Silurian rocks became squeezed between two relatively competent massifs, causing block faulting and rotation. The SMT seems to have acted as a rigid unit during this deformation, given that the declinations obtained from both sides of the Maam-Valley Faults are the same. A significant proportion of the regional rotation was accommodated by underthrusting on the Salrock Thrust and by the movement of smaller fault blocks.

\section{Conclusions}

Palaeomagnetic data from Llanvirn Ignimbrites, in an accreted Taconic arc in western Ireland, yield a primary remanence at fifteen sites (41 samples) in four flows with a mean direction $D=132.6^{\circ}$, $I=29.1^{\circ}, \alpha_{95}=17.9^{\circ}$ and a corresponding palaeopole at $036.4^{\circ} \mathrm{E}, 9.9^{\circ} \mathrm{S}$. This magnetisation is in reasonable agreement with existing Early to middle Ordovician reference poles for Laurentia and reveals no significant relative rotation between the terrane and the Laurentian margin after accretion. The lack of relative rotation has important implications for the evolution of the orogen in that the studied area has an E-W strike and not the NE-SW strike that typifies the orogen in most of the British Isles. We therefore conclude that the arcuate nature of this portion of the orogen existed from at least the middle Ordovician and most likely relates to the original geometry of the Laurentian margin in the region. The crustal rotations we have previously reported from Silurian sequences to the south of this study are considered to be the result of major Late Silurian and Early Devonian transpression with the present-day oroclinal pattern of those rocks being imposed on them by the pre-existing structural template.

\section{Acknowledgements}

We thank Peter Clift and John Geissman for thoughtful and helpful reviews and Tony Morris for his editorial handling. Jim Briden, Darren Randall, Trond Torsvik and Rob Van der Voo provided helpful discussions and suggestions. Mike Bracken and Paul Gaughan provided invaluable assistance in the field. We also thank Reidar Lovlie and Harald Walderhaug for the use of the Curie Balance in Bergen. Funding for this research was provided by a European Union Marie Curie Research Fellowship (ERBFMBICT950259) to C. Mac N., the Geological Survey of Norway and EOLAS (the Irish Research Council).

\section{References}

Beck Jr., M.E., 1980. Paleomagnetic record of plate-margin tectonic processes along the western edge of north America. J. 
Geophys. Res. 85, 7115-7131.

Briden, J.C., Robertson, D.J., Smethurst, M.A., 1989. Short paper: terrane rotations in the Irish Caledonides. J. Geol. Soc., London 146, 909-911.

Butler, R.F., 1992. Paleomagnetism: Magnetic Domains to Geologic Terranes. Blackwell, Boston, 319 pp.

Clift, P.D., Ryan, P.D., 1994. Geochemical evolution of an Ordovician island arc, South Mayo, Ireland. J. Geol. Soc., London 151, 329-342.

Demarest Jr., H.H., 1983. Error analysis for the determination of tectonic rotation from paleomagnetic data. J. Geophys. Res. $88,4321-4328$.

Deutsch, E.R., Somayajulu, C., 1969. Palaeomagnetism of Ordovician ignimbrites from Killary Harbour, Eire. Earth Planet. Sci. Lett. 7, 337-345.

Dewey, J.F., 1963. The Lower Palaeozoic stratigraphy of central Murrisk, County Mayo, Ireland, and the evolution of the south Mayo Trough. Q. J. Geol. Soc., London 119, 313-344.

Dewey, J.F., 1967. The structural and metamorphic history of the Lower Palaeozoic rocks of central Murrisk, County Mayo, Eire. Q. J. Geol. Soc., London 123, 125-155.

Dewey, J.F., Mange, M., 1999. Petrography of Ordovician and Silurian sediments in the western Irish Caledonides: tracers of a short-lived Ordovician continent-arc collision orogeny and the evolution of the Laurentian Appalachian/Caledonian margin. In: Mac Niocaill, C., Ryan, P.D. (Eds.), Continental Tectonics. Geol. Soc. London Spec. Publ., in press.

Dewey, J.F., Ryan, P.D., 1990. The Ordovician evolution of the South Mayo Trough, western Ireland. Tectonics 9, 887-901.

Fisher, R.A., 1953. Dispersion on a sphere. Proc. R. Soc., London A 217, 295-305.

Fortey, R.A., Harper, D.A.T., Ingham, J.K., Owen, A.W., Rushton, A.W., 1995. A revision of Ordovician series and stages from the historical type area. Geol. Mag. 132, 15-30.

Hutton, D.H.W., 1987. Strike-slip terranes and a model for the evolution of the British and Irish Caledonides. Geol. Mag. $125,405-500$.

Hutton, D.H.W., Alsop, G.I., 1996. The Caledonian strike-swing and associated lineaments in NW Ireland and adjacent areas: sedimentation, deformation and igneous intrusion patterns. J. Geol. Soc., London 153, 345-360.

Hutton, D.H.W., Dewey, J.F., 1986. Palaeozoic terrane accretion in the western Irish Caledonides. Tectonics 5, 1115-1124.

Mac Niocaill, C., Smethurst, M.A., 1994. The Palaeozoic palaeo- geography of Laurentia and its margins: a reassessment of palaeomagnetic data. Geophys. J. Int. 116, 715-725.

Max, M.D., Ryan, P.D., 1975. The Southern Uplands fault and its relation to the metamorphic rocks of Connemara. Geol. Mag. 112, 610-612.

McFadden, P.L., Jones, D.L., 1981. The fold test in palaeomagnetism. Geophys. J. R. Astron. Soc. 67, 53-58.

Morris, W.A., 1973. Palaeomagnetic Studies in the British Caledonides. Ph.D. Thesis, The Open University, U.K.

Robertson, D.J., 1988. Palaeomagnetism of the Connemara Gabbro, Western Ireland. Geophys. J. Int. 94, 51-64.

Ryan, P.D., Dewey, J.F., 1991. A geological and tectonic crosssection of the Caledonides of western Ireland. J. Geol. Soc., London 148, 173-180.

Ryan, P.D., Floyd, P.A., Archer, J.B., 1983. The stratigraphy and petrochemistry of the Lough Nafooey Group (Tremadocian), western Ireland. J. Geol. Soc., London 137, 443-458.

Ryan, P.D., Soper, N.J., Snyder, D.B., England, R.W., Hutton, D.H.W., 1995. The Antrim-Galway Line: a resolution of the Highland Border Fault enigma of the Caledonides of Britain and Ireland. Geol. Mag. 132, 171-184.

Smethurst, M.A., Briden, J.C., 1988. Palaeomagnetism of Silurian sediments in W Ireland: evidence for block rotation in the Caledonides. Geophys. J. Int. 95, 327-346.

Smethurst, M.A., Mac Niocaill, C., Ryan, P.D., 1994. Oroclinal bending in the Caledonides of western Ireland. J. Geol. Soc., London 151, 315-328.

Stanton, W.I., 1960. The lower Palaeozoic rocks of southwest Murrisk, Ireland. Q. J. Geol. Soc., London 116, 269-297.

Tucker, R.D., McKerrow, W.S., 1995. Early Paleozoic chronology: a review in light of new $\mathrm{U}-\mathrm{Pb}$ zircon ages from Newfoundland and Britain. Can. J. Earth Sci. 32, 368-379.

Williams, A., 1972. An Ordovician Whiterock fauna from western Ireland. Proc. R. Irish Acad. B72, 209-219.

Williams, D.M., 1990. Evolution of Ordovician terranes in western Ireland and their possible Scottish equivalents. Trans. R. Soc. Edinburgh 81, 23-29.

Williams, D.M., Harper, D.A.T., 1991. End-Silurian modifications of Ordovician terranes in western Ireland. J. Geol. Soc., London 148, 165-171.

Williams, D.M., Armstrong, H.A., Harper, D.A.T., 1988. The age of the South Connemara Group, Ireland, and its relationship to the Southern Uplands Zone of Scotland and Ireland. Scott. J. Geol. 24, 279-287. 